M.I. Martín, F. Andreola, L. Barbieri, F. Bondioli, I. Lancellotti, J.Ma. Rincón, M. Romero1. Crystallisation and microstructure of nepheline-forsterite glass-ceramics. Ceramics International, 39(2013) 2955-2966; doi: 10.1016/j.ceramint.2012.09.07240

\title{
Crystallisation and microstructure of nepheline-forsterite glass-ceramics
}

M.I. Martín ${ }^{1}$, F. Andreola ${ }^{2}$, L. Barbieri ${ }^{2}$, F. Bondioli ${ }^{2}$, I. Lancellotti ${ }^{2}$, J.Ma. Rincón ${ }^{1}$ and M. Romero,"*

${ }^{1}$ Group of Glass and Ceramic Materials, Department of Construction, Eduardo Torroja Institute for Construction Science (IETcc), CSIC. Serrano Galvache, 4, 28033 Madrid, Spain

${ }^{2}$ Dipartimento di Ingegneria dei Materiali e dell'Ambiente, Università degli Studi di Modena e Reggio Emilia. Via Vignolese, 905, 41125, Modena, Italy

*Corresponding author; E-mail address: mromero@ietcc.csic.es

\begin{abstract}
This work presents the results of a study focused on the development of forsterite-nepheline glass-ceramic with the use of rice husk ash (RHA) as a silica source. The glass-ceramics were produced by a sintering process of a glassy frit formulated in the $\mathrm{MgO}-\mathrm{Al}_{2} \mathrm{O}_{3}-\mathrm{SiO}_{2}$ base system with the addition of $\mathrm{B}_{2} \mathrm{O}_{3}$ and $\mathrm{Na}_{2} \mathrm{O}$ to facilitate the melting and pouring processes. The crystallisation study was carried out by depicting the TTT curve (Time-TemperatureTransformation). The mineralogical characterisation of the glass-ceramic materials was carried out using X-ray diffraction (XRD). The crystallisation activation energies were calculated by the Kissinger method. The results obtained show that devitrification of the RHA glass leads to a glass-ceramic material composed of nepheline $\left(\mathrm{Na}_{2} \mathrm{O} \cdot \mathrm{Al}_{2} \mathrm{O}_{3} \cdot 2 \mathrm{SiO}_{2}\right)$ and forsterite $\left(2 \mathrm{MgO} \cdot \mathrm{SiO}_{2}\right)$. A study of the microstructure by scanning electron microscopy (SEM) allowed to establish the morphological evolution in both the shape and spatial arrangement of the nepheline and forsterite crystals on heating.
\end{abstract}

Keywords: Sintering (A); Microstructure-final (B); Glass-ceramics (D); Forsterite-Nepheline 


\section{Introduction}

Glass-ceramics are established materials that exhibit advantageous thermal, optical, chemical, mechanical and electrical properties [1]. The great variety of compositions and the potential for the development of special microstructures with specific technological properties have allowed glass-ceramic materials to be used in a wide range of applications, such as kitchen cooktops [2], prostheses for surgical implants [3], glazes for ceramic tiles [4], telescope mirrors, radomes [5], insulators [1] and electronic packaging [6]. Glass-ceramics are produced from a parent glass by a sequential thermal process that involves controlled crystallisation, which consists of the growth of one or more crystalline phases within the vitreous mass [7]. The earliest glassceramics were produced by a conventional glass route and subsequently crystallised, usually by heat treatment in two stages to produce nucleation, which was followed by crystal growth. In recent years, the sintering method has proven to be a technically viable route for the manufacture of glass-ceramics. This process usually involves milling a glass frit into fine particles, which are then shaped by conventional forming techniques and subsequently heat treated to provide sintering and crystallisation of the glass particles. A sintering process is normally used when the parent glass exhibits a strong tendency for surface crystallisation or when complex shapes are required [8]. Because the most important forming systems are based on silicate compositions, the key crystalline phases of glass-ceramics are principally silicates [1].

Forsterite $\left(\mathrm{Mg}_{2} \mathrm{SiO}_{4}\right)$ is the magnesium rich end-member of the olivine solid solution series [9], and it is endowed with low electrical conductivity and a low dielectric constant, refractoriness and excellent insulation properties (even at high temperatures) and good biocompatibility. All of these favourable technological properties have led to the adoption of forsterite in many important technologies, including substrates for high-frequency electronics, ceramic-metal seals, the iron and steel industry, tunable lasers [10] and even as a bone implant material [11].

Forsterite has been synthesised by various techniques, including the conventional solid-state reaction of periclase $(\mathrm{MgO})$ and silica $\left(\mathrm{SiO}_{2}\right)$ [12], the mechanical activation of a talc and magnesium carbonate powder mixture [13], the polymer precursor method [14] and the sol-gel method [15]. However, the sintering temperature of forsterite is approximately $1500^{\circ} \mathrm{C}$, which is too high and limits its use. Many efforts have been made to improve the workability of forsterite, including reduction of the firing temperature by the addition of alumina [16] or low melting point glasses [17]. Another possible way to produce forsterite materials at lower temperatures is through the glass-ceramic process. Indeed, several investigations report the 
M.I. Martín, F. Andreola, L. Barbieri, F. Bondioli, I. Lancellotti, J.Ma. Rincón, M. Romero1. Crystallisation and microstructure of nepheline-forsterite glass-ceramics. Ceramics International, 39(2013) 2955-2966; doi: 10.1016/j.ceramint.2012.09.07240

devitrification of forsterite as a secondary crystalline phase in glass-ceramics belonging to different composition systems [18-22].

Nepheline $\left(\mathrm{NaAlSiO}_{4}\right)$ is a tectosilicate belonging to the also designated nepheline group $(\mathrm{Na}, \mathrm{K}) \mathrm{AlSiO}_{4}$. The nepheline phase is characterised by high chemical mechanical strength and impact resistance. Nepheline-based glass-ceramics are demonstrated to be suitable for use in microwave ovens [24] and dental applications [25,26]. Nepheline glass-ceramics are usually prepared from glasses of the $\mathrm{Na}_{2} \mathrm{O}-\mathrm{Al}_{2} \mathrm{O}_{3}-\mathrm{SiO}_{2}$ system and by the addition of different nucleating agents, such as $\mathrm{TiO}_{2}, \mathrm{Cr}_{2} \mathrm{O}_{3}, \mathrm{ZrO}_{2}$ or $\mathrm{LiF}$ to promote crystallisation [27,28].

Nepheline- and forsterite-containing glass-ceramics are normally prepared from high purity proportions of pure chemicals. They can also be prepared from cheaper raw materials such as wastes because the glass-ceramic process has been established as a suitable way to valorise mining and industrial wastes [29,30], including fly ash from incineration [31,32] and thermal power plants [4,33], wastes from hydrometallurgical processing plants [30], residual glass fibres from polyester matrix composites [34] and bagasse ashes [8], among others wastes. One residue that has experienced a significant increase in production in recent years is biomass ash, which originates from the combustion of biological material for energy purposes. It is clear that the current energy model in which more than $80 \%$ of energy production is based on fossil fuel consumption is not sustainable. For this reason, governments worldwide are implementing policies aimed at increasing the use of renewable energy resources. The use of biomass for energy purposes has multiple environmental benefits (i.e., reduction of $\mathrm{CO}_{2}$ emissions, nonproduction of solid particles and sulphur and nitrogen pollutants, stimulation of economic growth in rural areas, reduction of dependence on external fuel supplies, and re-use of wastes generated by agricultural activities).

Rice husk ash (RHA) is a waste material that is produced by burning rice husks; in particular, it is produced when rice husks are used as fuel for kilns to produce bricks and other clay products or in rice mills to generate steam for the parboiling process. Rice husks contain approximately $75 \%$ organic volatile matter and the balance of $25 \%$ of the weight is converted into ash during the firing process. This ash, which is known as RHA, is a carbon neutral green product that contains approximately 85-90 (wt\%) amorphous silica. Worldwide, approximately $120 \mathrm{Mt}$ of rice husk are produced annually, which gives rise to a global production of $21 \mathrm{Mt} /$ year of RHA [35]. In general, RHA is dumped as a waste [36,37]; however, because of its composition, it may be used as a source of silica in the steel industry [38] and as a pozzolanic material for the cement industry $[39,40]$. In the ceramic sector, several studies have been conducted in recent 
M.I. Martín, F. Andreola, L. Barbieri, F. Bondioli, I. Lancellotti, J.Ma. Rincón, M. Romero1. Crystallisation and microstructure of nepheline-forsterite glass-ceramics. Ceramics International, 39(2013) 2955-2966; doi: 10.1016/j.ceramint.2012.09.07240

years to valorise RHA. In particular, the use of this ash has been investigated as a secondary raw material in the manufacture of whiteware products [41], pigments [36,42], glazes [37,43], brick compositions [44] and glass-ceramic materials in the $\mathrm{SiO}_{2}-\mathrm{Na}_{2} \mathrm{O}-\mathrm{CaO}$ [45] and $\mathrm{SiO}_{2}-\mathrm{Al}_{2} \mathrm{O}_{3}-\mathrm{Li}_{2} \mathrm{O}$ [46] systems, as well as in cordierite-based glass-ceramics [47].

In a recent paper [35], the authors have demonstrated the feasibility of producing forsteritenepheline-based glasses from a RHA mixture that incorporates $\mathrm{B}_{2} \mathrm{O}_{3}$ and $\mathrm{Na}_{2} \mathrm{O}$ to facilitate the melting process. Significant environmental benefits are attained by using RHA as source of silica: (a) avoided landfill disposal of the residue; (b) minimization of the natural raw materials consumption. Besides, the RHA is a not hazardous residue, so the materials resulted do not cause further damage (environmental impact). These glasses could lead to glass-ceramics that combine the beneficial properties associated with both the forsterite (low electrical conductivity, low dielectric constant, refractoriness and excellent insulation properties) and nepheline (high mechanical strength and impact resistance) crystalline phases. The development of a material that combines these properties could find many applications, such as building material (ceramic tiles) in which these properties are required. It is known that the nature of the devitrified crystalline phases, as well as their shape, size and spatial arrangement, are the most important factors that affect the technical properties of glass-ceramics. Therefore, the aim of this work is to study the evolution of the crystalline phases and microstructures during the crystallisation process of a forsterite-nepheline-based glass produced from RHA as a silica source.

\section{Materials and methods}

A glass (hereafter designated RHA glass) in the $\mathrm{SiO}_{2}-\mathrm{Al}_{2} \mathrm{O}_{3}-\mathrm{MgO}-\mathrm{Na}_{2} \mathrm{O}$ base system was formulated with rice husk ash from a plant producing semi-parboiled rice as a silica source (Garibaldi 1889, Colussi S.p.A., Milan, Italia). Prior to its use, the ash was sieved to a particle size $<250 \mu \mathrm{m} . \mathrm{B}_{2} \mathrm{O}_{3}$ and $\mathrm{Na}_{2} \mathrm{O}$ (as $\mathrm{Na}_{2} \mathrm{CO}_{3}$ ) were added to the ash to facilitate the melting process. The chemical reagents used (all of A.R. quality) were $\mathrm{Al}_{2} \mathrm{O}_{3}, \mathrm{MgO}, \mathrm{B}_{2} \mathrm{O}_{3}$ and $\mathrm{Na}_{2} \mathrm{CO}_{3}$. The components $\left(46.52 \%\right.$ ash, $13.84 \% \mathrm{Al}_{2} \mathrm{O}_{3}, 13.16 \% \mathrm{MgO}, 22.17 \% \mathrm{Na}_{2} \mathrm{CO}_{3}$ and $4.33 \%$ $\mathrm{B}_{2} \mathrm{O}_{3}$ ) were mixed for 30 minutes in a blender (TURBULA) to produce a homogeneous mixture. The batch was placed in an aluminosilicate crucible and heated at $10^{\circ} \mathrm{C} / \mathrm{min}$ in an electric furnace up to $1450^{\circ} \mathrm{C}$. After a holding time of $120 \mathrm{~min}$ at the melting temperature, the melt was quenched by pouring into water, producing a glass frit. 
M.I. Martín, F. Andreola, L. Barbieri, F. Bondioli, I. Lancellotti, J.Ma. Rincón, M. Romero1. Crystallisation and microstructure of nepheline-forsterite glass-ceramics. Ceramics International, 39(2013) 2955-2966; doi: 10.1016/j.ceramint.2012.09.07240

The chemical compositions of the RHA and glass frit were determined by X-ray fluorescence (XRF) (Thermo Scientific model ARL ADVANT'XP) and inductively coupled plasma (ICP) (Varian model Liberty 200), respectively.

The activation energy for crystallisation was calculated by differential scanning calorimetry (DSC) (SETARAM model Labsys) on powder samples $(<63 \mu \mathrm{m})$. The samples were heated from $25^{\circ}$ to $1450^{\circ} \mathrm{C}$ at heating rates of $10^{\circ}, 20^{\circ}, 30^{\circ}, 40^{\circ}$ and $50^{\circ} \mathrm{C} / \mathrm{min}$. The DSC scans were conducted under flowing air, in platinum crucibles and calcined $\mathrm{Al}_{2} \mathrm{O}_{3}$ was used as a reference material. The DSC curves were normalised with respect to the sample weight. The data were analysed using the Kissinger method [48]:

$\operatorname{Ln}\left(\beta / T_{p}^{2}\right)=-E / R \cdot T_{p}+$ constant

where $T_{p}$ is the maximum of the DSC crystallisation peak, $\beta$ is the heating rate, $E$ is the activation energy and $R$ is the ideal gas constant.

The development of the crystalline phases after heating of the final glass-ceramics was studied on compacted glass samples. Powdered glass $(<63 \mu \mathrm{m})$ was moistened by spraying with distilled water $(2 \mathrm{wt} \%)$. Compacts $(1 \times 1 \mathrm{~cm})$ were shaped by uniaxial pressing (Nannetti $\mathrm{S}$ hydraulic press) at $40 \mathrm{MPa}$ in a steel die. The glass compacts were thermally treated at different temperatures $\left(650-1000^{\circ} \mathrm{C}\right)$ for several times $(2-60 \mathrm{~min})$. After treatment, the samples were taken out of the oven and cooled to room temperature.

The evaluation of the amorphous nature of the glass after melting and the mineralogical study of the crystalline phases devitrified after the thermal treatment was performed by X-ray diffraction (XRD) (Philips model X 'PERT MPD) with Ni-filtered $\mathrm{Cu} \mathrm{K \alpha}$ radiation operating at $30 \mathrm{~mA}$ and $50 \mathrm{kV}$. Data were recorded in the $3-75^{\circ} 2 \theta$ range (step size $0.019732^{\circ}$ and $0.5 \mathrm{~s}$ counting time for each step).

The microstructural analysis of the glass-ceramic materials was performed by field emission scanning electron microscopy (FESEM) (JEOL model JSM 6500F) using an accelerating voltage of $20 \mathrm{kV}$. The SEM specimens were polished using 6, 3 and $1 \mu \mathrm{m}$ diamond pastes after grinding with silicon carbide paper and water. The polished surfaces were etched for $10 \mathrm{~s}$ in a 5 vol\% HF solution, washed ultrasonically with distilled water and ethyl alcohol, dried and subsequently Au-Pd coated in a Balzers SCD 050 sputter. Semi-quantitative analysis of the different phases was performed by energy dispersive X-ray spectroscopy (EDS) with a Link eXL detector provided by a beryllium (Be) window. The distribution of the $\mathrm{Na}$ and $\mathrm{Mg}$ ions 
M.I. Martín, F. Andreola, L. Barbieri, F. Bondioli, I. Lancellotti, J.Ma. Rincón, M. Romero1. Crystallisation and microstructure of nepheline-forsterite glass-ceramics. Ceramics International, 39(2013) 2955-2966; doi: 10.1016/j.ceramint.2012.09.07240

among the different crystalline phases was determined by means of digital X-ray mapping, which is an imaging technique that is used to examine the two-dimensional distribution of elements in a specimen. Each two-dimensional map represents a single element and the colour variations on the map represent differences in the weight percent of the elements from point to point.

To a first evaluation of the technological properties, the glass-ceramic crystallized for 40 minutes $900^{\circ} \mathrm{C}$ were tested to determine the water absorption (ASTM C373-88), Mohs hardness using a laboratory kit (Gabbrielli srl) and bending strength (UNE-EN 843-1) in an electronic universal tester (Servosis model ME-402/01) on ten test pieces of 50x10x3 $\mathrm{mm}$ by a three point loading test with a span of $32 \mathrm{~mm}$ and a crosshead speed of $1 \mathrm{~mm} / \mathrm{min}$.

\section{Results and discussion}

Table 1 shows the chemical composition of the rice husk ash and the derived RHA glass. The major component of the ash is $\mathrm{SiO}_{2}$, and $\mathrm{P}_{2} \mathrm{O}_{5}$ shows the highest concentration among the minor components. $\mathrm{SiO}_{2}, \mathrm{Al}_{2} \mathrm{O}_{3}, \mathrm{Na}_{2} \mathrm{O}_{3}$ and $\mathrm{MgO}$ are the main components of the RHA glass. When the glass composition is represented in the $\mathrm{SiO}_{2}-\mathrm{Al}_{2} \mathrm{O}_{3}-\mathrm{Na}_{2} \mathrm{O}$ (Fig. 1a), $\mathrm{SiO}_{2}-\mathrm{Al}_{2} \mathrm{O}_{3}-\mathrm{MgO}$ (Fig. 1b) and nepheline-forsterite- $\mathrm{SiO}_{2}$ (Fig. 1c) composition systems, it is located in the crystallisation fields of cordierite $\left(\mathrm{Mg}_{2} \mathrm{Al}_{4} \mathrm{Si}_{5} \mathrm{O}_{18}\right)$, nepheline $\left(\mathrm{Na}_{2} \mathrm{Al}_{2} \mathrm{Si}_{2} \mathrm{O}_{8}\right)$ and spinel $\left(\mathrm{MgAl}_{2} \mathrm{O}_{4}\right)$, respectively.

Table 1. Chemical composition (wt\%) of rice husk ash and RHA glass.

\begin{tabular}{lcl}
\hline \multicolumn{1}{c}{ Oxide } & Rice husk ash & RHA glass \\
\hline $\mathrm{SiO}_{2}$ & 90.75 & 44.18 \\
$\mathrm{Al}_{2} \mathrm{O}_{3}$ & 0.06 & 18.22 \\
$\mathrm{CaO}$ & 1.20 & 0.68 \\
$\mathrm{MgO}$ & 0.84 & 12.24 \\
$\mathrm{~K}_{2} \mathrm{O}$ & 1.56 & 1.86 \\
$\mathrm{Fe}_{2} \mathrm{O}_{3}$ & 0.16 & 0.06 \\
$\mathrm{P}_{2} \mathrm{O}_{5}$ & 3.62 & 0.48 \\
$\mathrm{Na}_{2} \mathrm{O}$ & --- & 17.06 \\
$\mathrm{~B}_{2} \mathrm{O}_{3}$ & --- & 5.21 \\
$\mathrm{TiO}_{2}$ & 0.03 & --- \\
$\mathrm{ZnO}_{\mathrm{SO} O}$ & 0.01 & --- \\
$\mathrm{SO}_{3}$ & 1.62 & --- \\
$\mathrm{MnO}$ & 0.16 & --- \\
\hline
\end{tabular}


M.I. Martín, F. Andreola, L. Barbieri, F. Bondioli, I. Lancellotti, J.Ma. Rincón, M. Romero1. Crystallisation and microstructure of nepheline-forsterite glass-ceramics. Ceramics International, 39(2013) 2955-2966; doi: 10.1016/j.ceramint.2012.09.07240

Fig. 2a depicts the DSC curves for powder $(<63 \mu \mathrm{m})$ and bulk RHA glass recorded at $50^{\circ} \mathrm{C} / \mathrm{min}$. The figure shows that the devitrification process of RHA glass occurred through a surface crystallisation mechanism [35]. Thus, the most effective method for manufacturing glassceramic materials from RHA glass is by a sinter-crystallisation process, which involves the sintering and subsequent crystallisation of powdered glass. Therefore, the crystallisation study described below was performed on a glass sample that was ground and sieved to a particle size $<63 \mu \mathrm{m}$.

The first endothermic jump in the baseline at $\approx 600^{\circ} \mathrm{C}$ corresponds to the glass transition temperature (Tg). After the $\mathrm{Tg}$, two exothermic effects centred at $\approx 745$ and $900^{\circ} \mathrm{C}$ indicate that the RHA glass is unstable on heating; thus, subsequent thermal treatment leads to a crystallisation process with the consequent formation of a glass-ceramic material. Finally, an endothermic reaction starting at $\approx 1100^{\circ} \mathrm{C}$ indicates the formation of liquid phases. The XRD patterns collected on glass samples that were thermally treated for 60 min [35] indicate that the first exothermic effect $\left(745^{\circ} \mathrm{C}\right)$ corresponds to the crystallisation of nepheline $\left(\mathrm{Na}_{2} \mathrm{O} \cdot \mathrm{Al}_{2} \mathrm{O}_{3} \cdot 2 \mathrm{SiO}_{2}\right)$ from the parent glass, whereas the formation of forsterite $\left(2 \mathrm{MgO} \cdot \mathrm{SiO}_{2}\right)$ is responsible for the crystallisation effect centred at $900^{\circ} \mathrm{C}$.

Fig. $2 \mathrm{~b}$ shows the plot of $\ln \left(\beta / \mathrm{Tp}^{2}\right)$ versus $1 / \mathrm{T}_{\mathrm{p}}$. A linear relationship was obtained for both crystallisation peaks, in accordance with the Kissinger equation (eqn. 1). The values of the activation energy (E) calculated from the slopes of these plots are $391 \mathrm{~kJ} / \mathrm{mol}$ and $160 \mathrm{~kJ} / \mathrm{mol}$ for the first and second crystallisation peaks, respectively. The value of $\mathrm{E}$ for the nepheline crystallisation (first DSC peak) is almost $150 \%$ greater than that corresponding to the formation of forsterite. This differentiation in the values of the activation energy leads to differences in the degree of development of both crystalline phases after the crystallisation process, as explained below.

Fig. 3 presents the TTT (Time-Temperature-Transformation) diagrams for the RHA glass. The C-shaped curve, which is characteristic of nucleation and growth processes, shows the combinations of time and temperature needed for the onset of crystallisation. As usual in TTT curves, the lower heat treatment temperatures require longer times to initiate crystallisation; thus, the glass begins to devitrify after 40 minutes at $700^{\circ} \mathrm{C}$. As the temperature increases, the time required for the onset of crystallisation is reduced; consequently, the glass compacts are fully devitrified after 15 minutes at $750^{\circ} \mathrm{C}$. The fastest rates of crystallisation occurred at the highest temperatures employed $\left(950\right.$ and $\left.1000^{\circ} \mathrm{C}\right)$, for which the onset time was only 2 minutes. 
M.I. Martín, F. Andreola, L. Barbieri, F. Bondioli, I. Lancellotti, J.Ma. Rincón, M. Romero1. Crystallisation and microstructure of nepheline-forsterite glass-ceramics. Ceramics International, 39(2013) 2955-2966; doi: 10.1016/j.ceramint.2012.09.07240
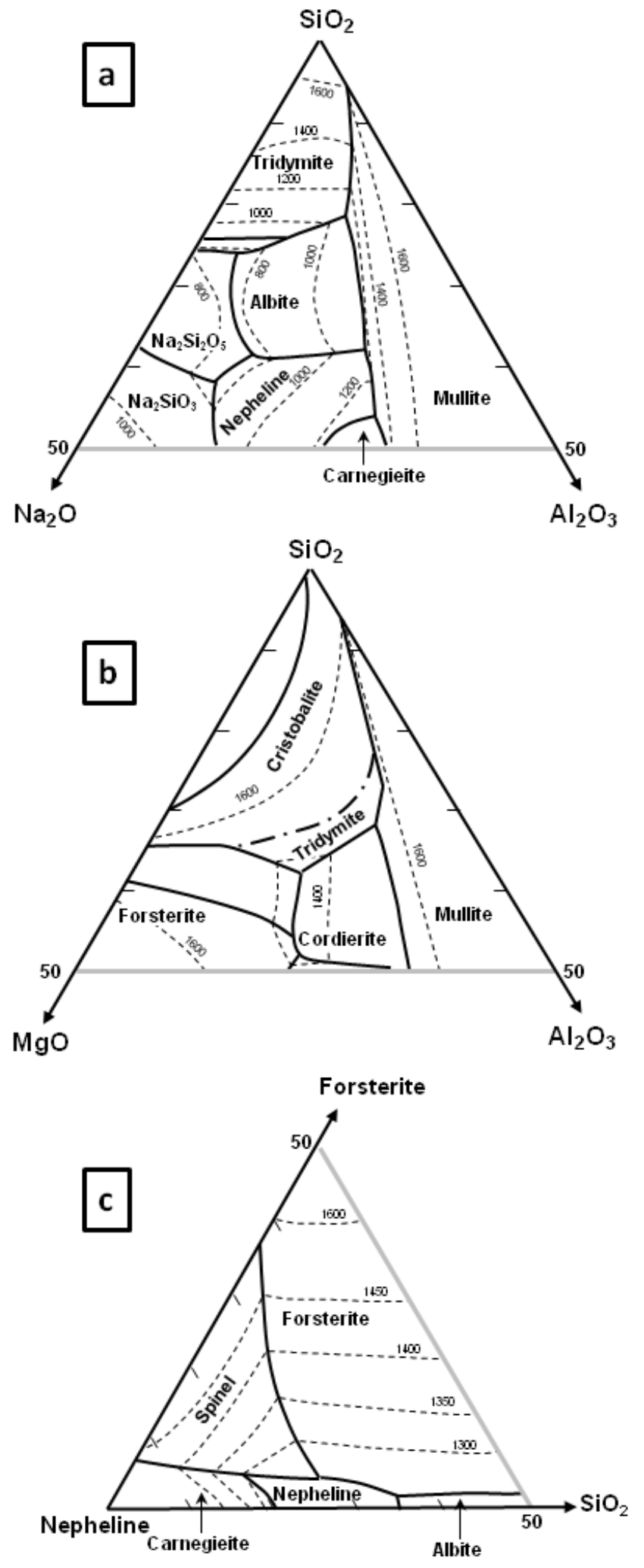

Fig. 1. Phase diagrams (wt $\%, \mathrm{~T}$ in ${ }^{\circ} \mathrm{C}$ ) of the a) $\mathrm{SiO}_{2}-\mathrm{Al}_{2} \mathrm{O}_{3}-\mathrm{Na}_{2} \mathrm{O}$ system, b) $\mathrm{SiO}_{2}-\mathrm{Al}_{2} \mathrm{O}_{3}-\mathrm{MgO}$ system and c) nepheline-forsterite- $\mathrm{SiO}_{2}$ system indicating the $\mathrm{RHA}$ glass composition ( $\vec{\sim}$ ). 
M.I. Martín, F. Andreola, L. Barbieri, F. Bondioli, I. Lancellotti, J.Ma. Rincón, M. Romero1. Crystallisation and microstructure of nepheline-forsterite glass-ceramics. Ceramics International, 39(2013) 2955-2966; doi: 10.1016/j.ceramint.2012.09.07240

a)

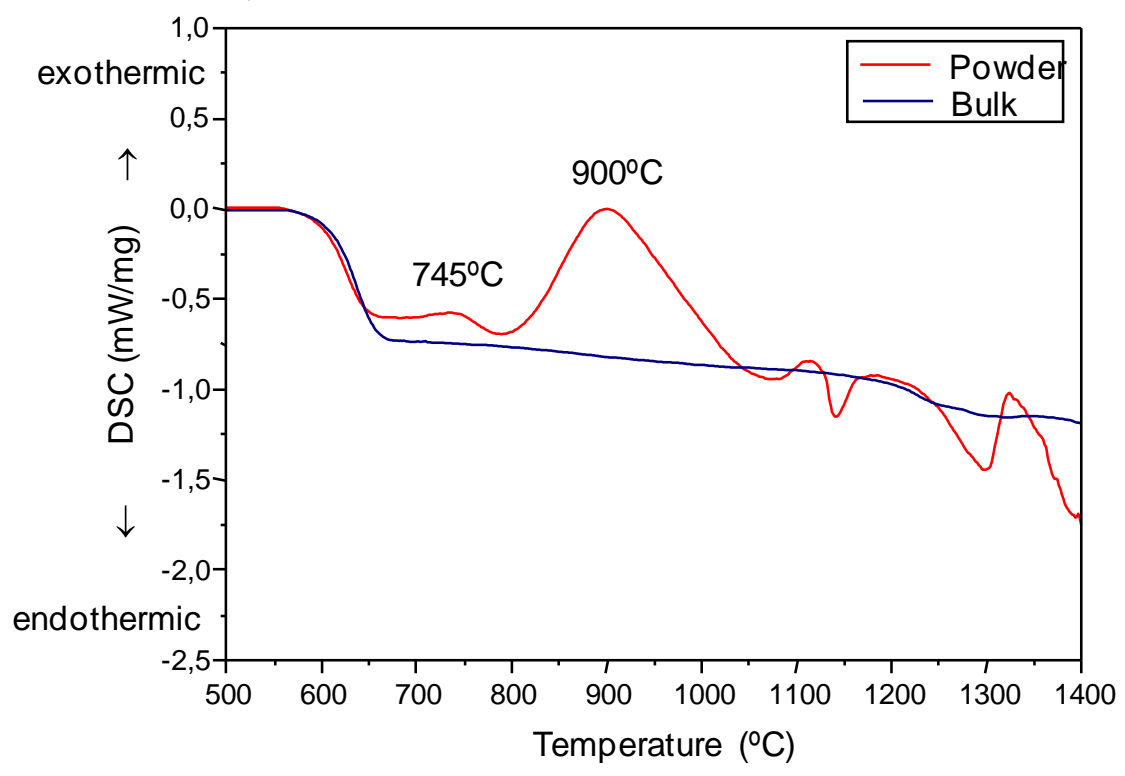

b)

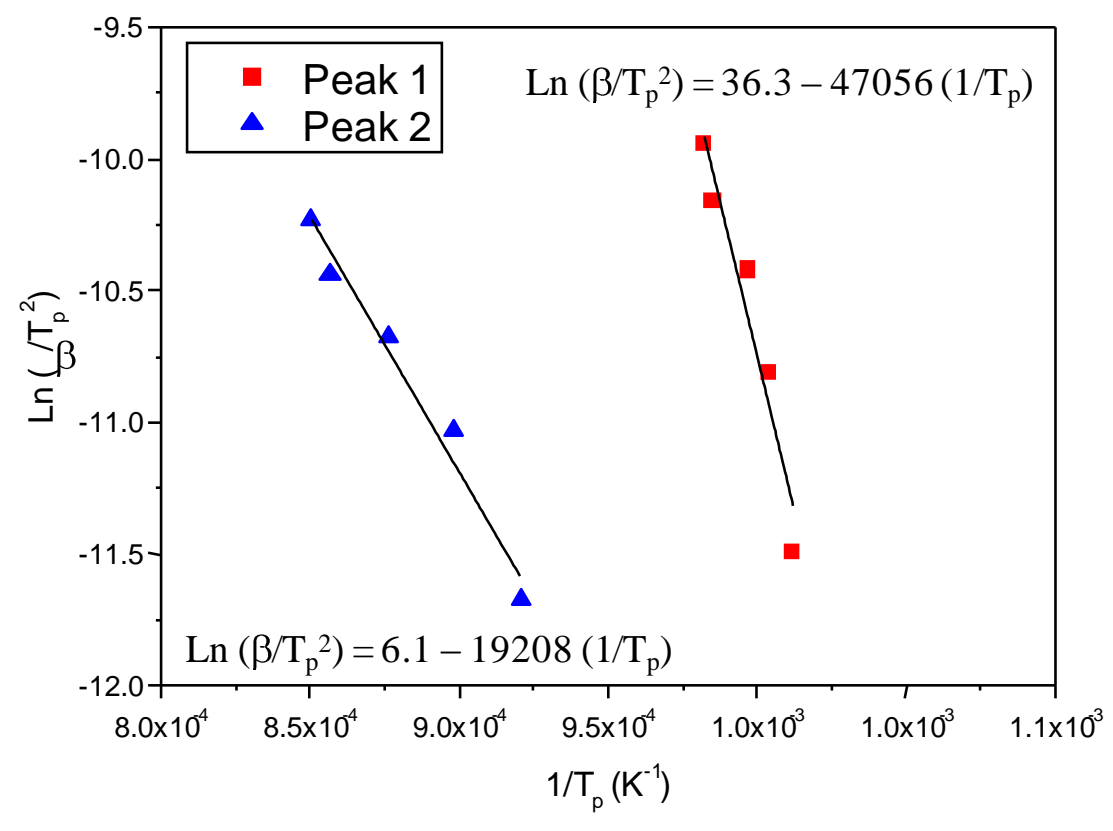

Fig. 2. a) DSC curve $\left(25-1450^{\circ} \mathrm{C}, 50^{\circ} \mathrm{C} / \mathrm{min}\right)$ recorded on bulk and powder $(<63 \mu \mathrm{m}) \mathrm{RHA}$ glass, b) Determination of the activation energy for crystallisation by the Kissinger equation (Peak 1 and Peak 2 correspond to the exotherms at 745 and $903^{\circ} \mathrm{C}$ respectively). 


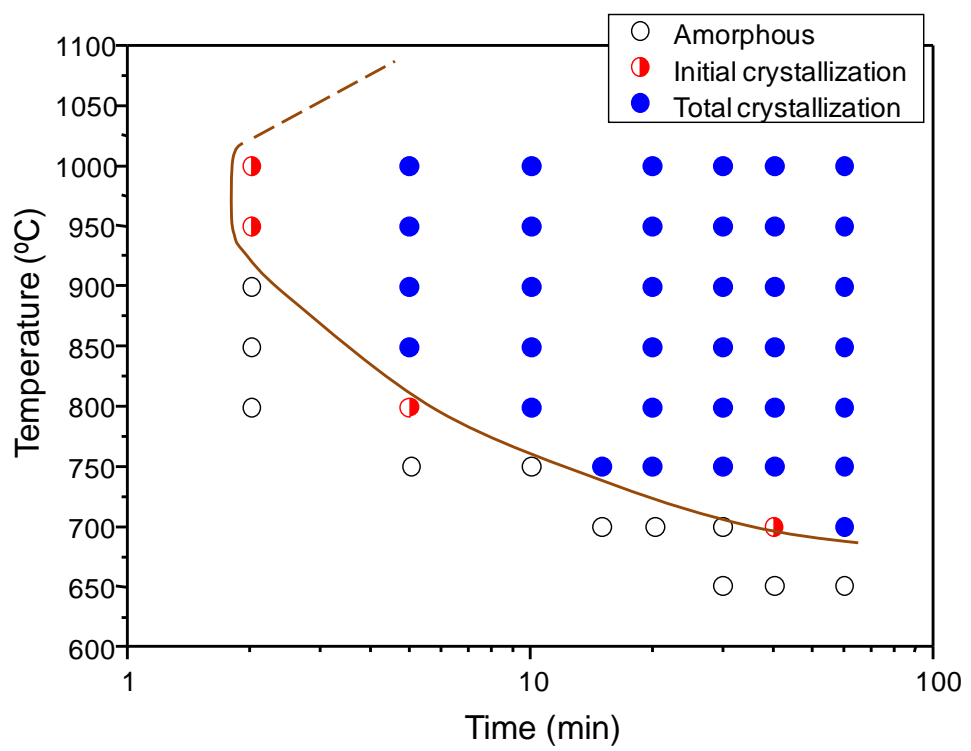

Fig. 3. TTT curve for RHA glass.

The XRD study conducted on all samples after heat treatment showed that devitrification of the RHA glass leads to a glass-ceramic material composed of nepheline $\left(\mathrm{Na}_{2} \mathrm{O} \cdot \mathrm{Al}_{2} \mathrm{O}_{3} \cdot 2 \mathrm{SiO}_{2}\right)$ and forsterite $\left(2 \mathrm{MgO} \cdot \mathrm{SiO}_{2}\right)$. Fig. 4 shows the intensity evolution (obtained from the collected data) of both crystalline phases as a function of temperature $\left(700-1000^{\circ} \mathrm{C}\right)$ and time $(2-60 \mathrm{~min})$. The diffraction lines at 2.46 and $3.40 \AA$ for forsterite and nepheline, respectively, have been selected for the representation. It is important to note that nepheline and forsterite crystallise simultaneously during most of the heat treatments tested, although their respective crystallisation processes do not overlap in the DSC curve. This result is probably caused by the difference in the values of their respective activation energies, as determined by the Kissinger method. The onset of nepheline crystallisation is located at $700^{\circ} \mathrm{C}$ in the DSC curve (Fig. 2a). The high activation energy associated with this process $(391 \mathrm{~kJ} / \mathrm{mol})$ implies that a long holding time is required to promote the beginning of crystallisation; thus, nepheline is only detected by $\mathrm{XRD}$ after $40 \mathrm{~min}$ at $700^{\circ} \mathrm{C}$. This temperature is lower than that corresponding to the onset of forsterite crystallisation $\left(\approx 800^{\circ} \mathrm{C}\right)$. However, because of its lower activation energy (160 $\mathrm{kJ} / \mathrm{mol}$ ), the holding time of $60 \mathrm{~min}$ is adequate to promote crystallisation in an isothermal process. Consequently, a minor quantity of forsterite is also detected after thermal treatment at $700^{\circ} \mathrm{C} / 60 \mathrm{~min}$. In the treatment at $750^{\circ} \mathrm{C}$, the temperature is close to the maximum of the nepheline exothermic peak; consequently, the diffractograms taken on samples heated at $750^{\circ} \mathrm{C}$ for 40 and $60 \mathrm{~min}$ reach the maximum X-ray intensity for the nepheline phase. As the 
M.I. Martín, F. Andreola, L. Barbieri, F. Bondioli, I. Lancellotti, J.Ma. Rincón, M. Romero1. Crystallisation and microstructure of nepheline-forsterite glass-ceramics. Ceramics International, 39(2013) 2955-2966; doi: 10.1016/j.ceramint.2012.09.07240

temperature increases, the intensity of nepheline in the patterns decreases, while that of forsterite increases, reaching its maximum after the treatment at $1000^{\circ} \mathrm{C}$ for $40 \mathrm{~min}$.

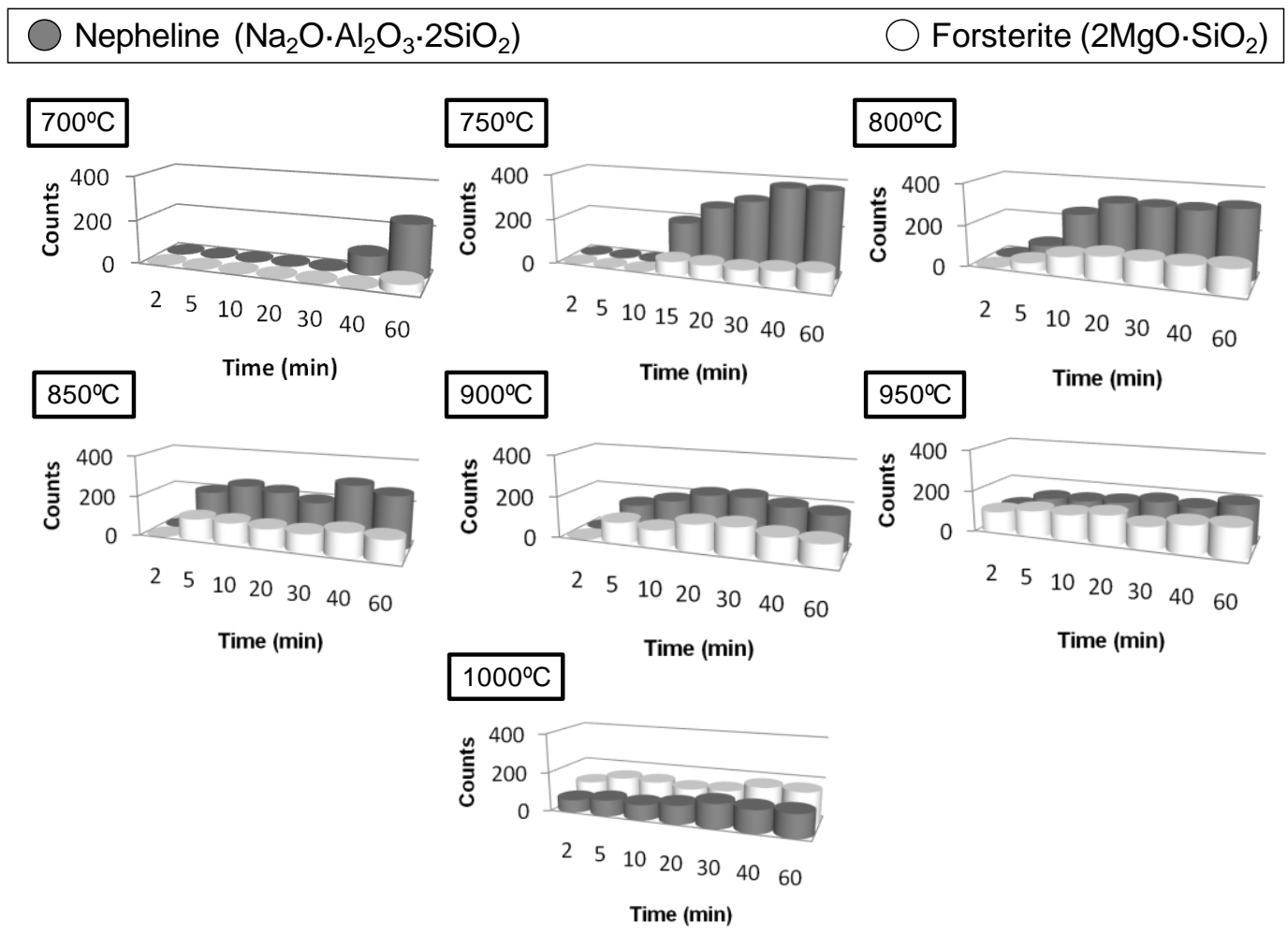

Fig. 4. Evolution of X-ray intensity for nepheline and forsterite phases as a function of temperature and time $\left(\mathrm{T}=700-1000^{\circ} \mathrm{C}\right.$ and $\left.\mathrm{t}=2-60 \mathrm{~min}\right)$.

Fig. 5 presents low magnification FESEM images of RHA glass samples heat-treated at various temperatures $\left(700-1000^{\circ} \mathrm{C}\right)$ for 40 minutes. The glass bodies exhibit good sintering behaviour and the fired samples show a homogeneous microstructure that is free of internal defects, such as delaminations or cracks. The crystallisation process takes places according to a mechanism of controlled surface crystallisation in which dense aggregates of crystals grow along the border line of the former glass grains. In the early stages of crystal growth $\left(700^{\circ} \mathrm{C}\right)$, the glass-ceramic exhibits a typical coast-and-island microstructure [1] that is characterised by crystal conglomerates that form a coast, while the glassy phase enclosed by the crystals has an islandlike appearance. At $700^{\circ} \mathrm{C}$, a significant extent of open porosity is noticeable, which consists of interconnected elongated pores that produce channels along the glass-crystal interface. When crystallisation proceeds, the crystals grow inside the remaining glass, the phase boundaries disappear and the coasts and islands are indistinguishable. The glass-ceramic produced at $750^{\circ} \mathrm{C}$ exhibits a high degree of crystallisation with a microstructure that consists of a significant concentration of crystals together with a residual glassy phase constrained to the centre of the 
M.I. Martín, F. Andreola, L. Barbieri, F. Bondioli, I. Lancellotti, J.Ma. Rincón, M. Romero1. Crystallisation and microstructure of nepheline-forsterite glass-ceramics. Ceramics International, 39(2013) 2955-2966; doi: 10.1016/j.ceramint.2012.09.07240

larger former glass particles. Open porosity is still perceptible, although the channels observed at $700^{\circ} \mathrm{C}$ are no longer detected. As the temperature increases, the open porosity is reduced, but close porosity consisting of rounded pores increases simultaneously. Furthermore, temperatures above $900^{\circ} \mathrm{C}$ cause an increase in the glassy phase, which is likely caused by the partial dissolution of the nepheline phase developed at lower temperatures (Fig. 4).
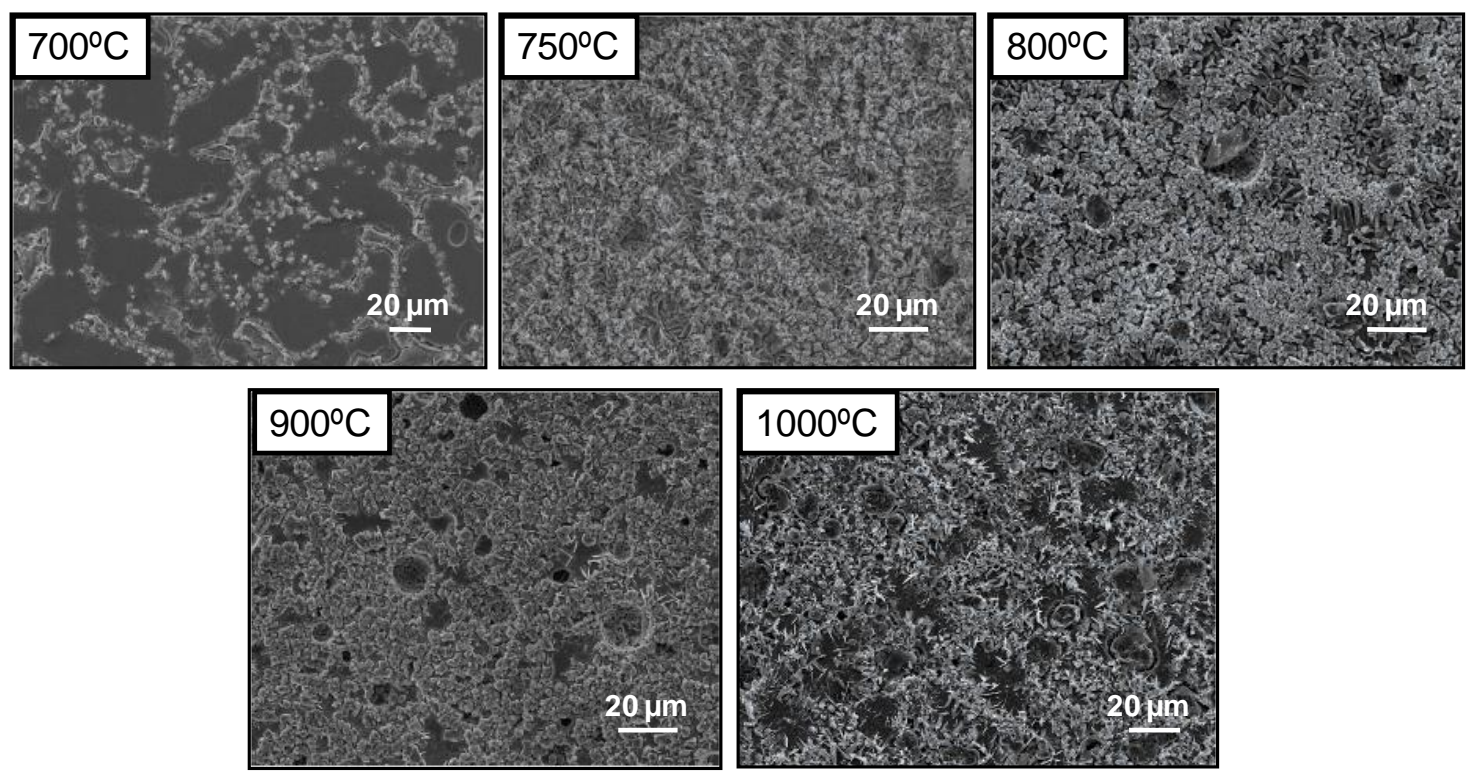

Fig. 5. Secondary electron images of RHA samples heat-treated at different temperatures (700$1000^{\circ} \mathrm{C}$ ) for 40 minutes.

Figs. 6-11 show FESEM images and XRD patterns of the glass-ceramics produced at the temperature-time conditions indicated in Fig. 5. Table 2 collects the EDX analyses of the glassy and crystalline phases observed in the glass-ceramic materials after the different thermal treatments. The XRD diffractogram of the material produced after thermal treatment at $700^{\circ} \mathrm{C} / 40 \mathrm{~min}$ (Fig. 6a) shows that the crystallisation process begins with the precipitation of nepheline, although the amount of the glassy phase in the glass-ceramic remains significant, as indicated by the intensity of the amorphous halo. Fig. 6b shows that nepheline crystals $(\mathrm{N})$ outline the coast in the coast-and-island microstructure described above. At $700^{\circ} \mathrm{C}$, the crystalline and glassy phases exhibit a similar chemical composition (Table 2), the main difference between them is their $\mathrm{MgO}$ content, which preferentially remains in the residual glass. It should be noted that the $\mathrm{SiO}_{2} / \mathrm{Al}_{2} \mathrm{O}_{3}$ ratio in the nepheline crystals is 2.36 , which is twice the ratio corresponding to the stoichiometric nepheline composition with $\mathrm{SiO}_{2} / \mathrm{Al}_{2} \mathrm{O}_{3}=1.18$ [49]. The usual morphology of nepheline crystals is stout prisms [50]. 
M.I. Martín, F. Andreola, L. Barbieri, F. Bondioli, I. Lancellotti, J.Ma. Rincón, M. Romero1. Crystallisation and microstructure of nepheline-forsterite glass-ceramics. Ceramics International, 39(2013) 2955-2966; doi: 10.1016/j.ceramint.2012.09.07240
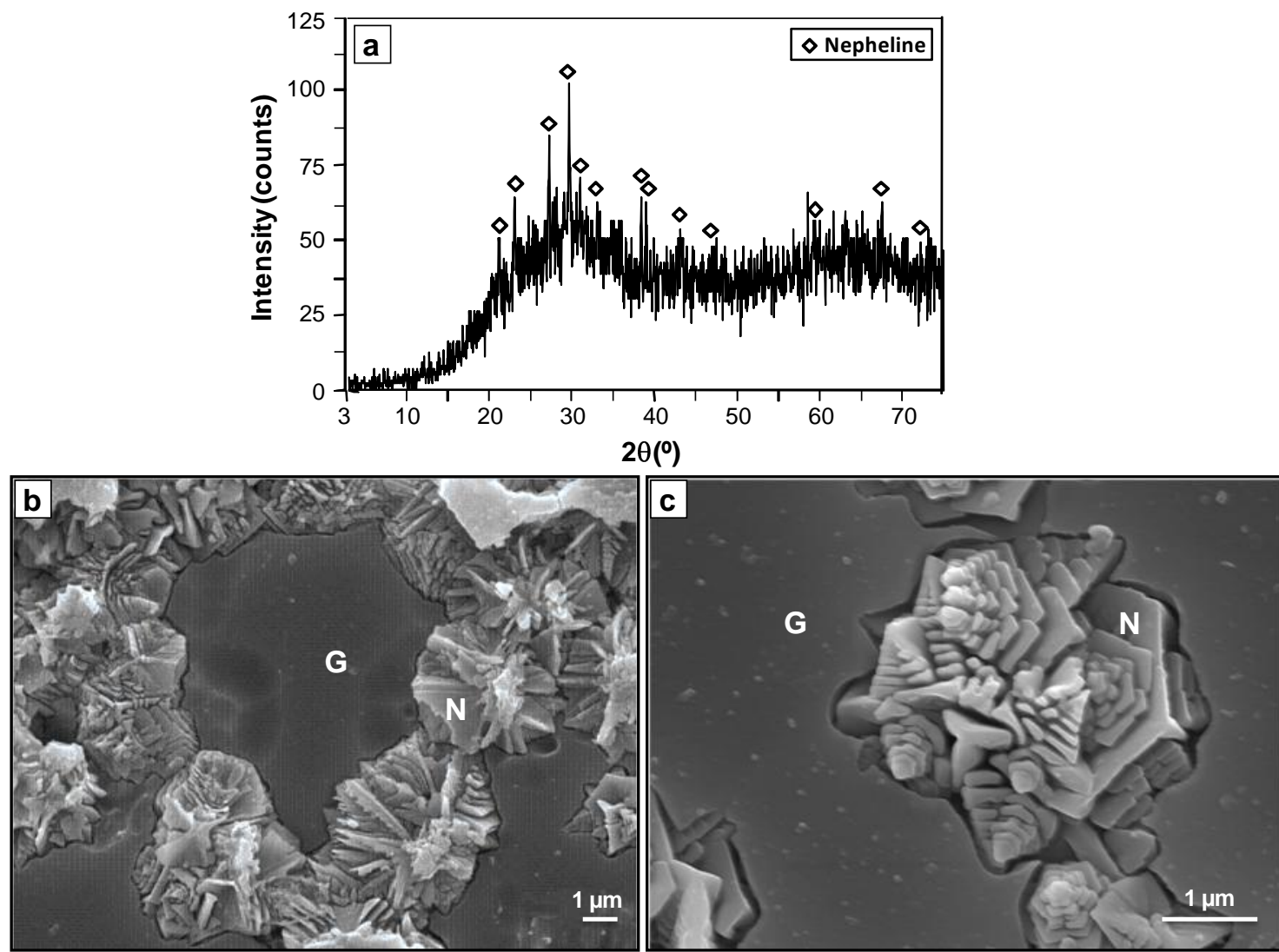

Fig. 6. XRD pattern (a) and secondary electron images (b) 6000x and (c) 18000x of samples heat-treated at $700^{\circ} \mathrm{C}$ for 40 minutes $(\mathrm{G}=$ glassy phase, $\mathrm{N}=$ nepheline $)$.

Table 2. EDS analyses (wt\%) of the glassy and crystalline phases of RHA glass heat treated at different temperatures.

\begin{tabular}{lllllllc}
\hline Thermal treatment & Phase & $\mathbf{S i O}_{2}$ & $\mathbf{A l}_{2} \mathbf{O}_{3}$ & $\mathbf{N a}_{2} \mathbf{O}$ & $\mathbf{K}_{2} \mathbf{O}$ & $\mathbf{M g O}$ & $\mathbf{S i O}_{2} / \mathbf{M g O}$ \\
\hline \multirow{2}{*}{$700^{\circ} \mathrm{C} / 40 \mathrm{~min}$} & Glassy phase & 52.99 & 18.86 & 15.65 & 1.10 & 11.40 & 4.65 \\
& Nepheline & 54.48 & 23.10 & 15.80 & 0.90 & 5.73 & \\
\hline \multirow{3}{*}{$750^{\circ} \mathrm{C} / 40 \mathrm{~min}$} & Glassy phase & 56.08 & 17.70 & 14.46 & 1.65 & 10.10 & 5.55 \\
& Nepheline & 54.35 & 24.42 & 17.04 & 1.22 & 2.98 & \\
& Forsterite & 51.10 & 16.61 & 9.88 & 1.09 & 21.32 & 2.40 \\
\hline \multirow{3}{*}{$800^{\circ} \mathrm{C} / 40 \mathrm{~min}$} & Glassy phase & 56.11 & 13.34 & 18.02 & 1.20 & 11.34 & 4.95 \\
& Nepheline & 53.06 & 24.55 & 15.59 & 1.38 & 5.43 & \\
& Forsterite & 54.35 & 14.24 & 8.35 & 0.48 & 27.84 & 1.95 \\
\hline \multirow{3}{*}{$900^{\circ} \mathrm{C} / 40 \mathrm{~min}$} & Glassy phase & 57.58 & 16.88 & 16.03 & 1.03 & 8.49 & 6.78 \\
& Nepheline & 53.02 & 25.97 & 16.04 & 1.19 & 3.77 & \\
& Forsterite & 50.32 & 12.74 & 7.99 & 0.76 & 28.18 & 1.78 \\
\hline \multirow{3}{*}{$1000^{\circ} \mathrm{C} / 40 \mathrm{~min}$} & Glassy phase & 57.16 & 19.54 & 14.01 & 1.31 & 8.20 & 6.97 \\
& Nepheline & 52.27 & 22.85 & 15.41 & 0.81 & 8.67 & \\
& Forsterite & 48.28 & 10.12 & 17.04 & 0.72 & 33.84 & 1.42 \\
\hline
\end{tabular}


M.I. Martín, F. Andreola, L. Barbieri, F. Bondioli, I. Lancellotti, J.Ma. Rincón, M. Romero1. Crystallisation and microstructure of nepheline-forsterite glass-ceramics. Ceramics International, 39(2013) 2955-2966; doi: 10.1016/j.ceramint.2012.09.07240

Nevertheless, the detailed observation of the microstructure developed at $700^{\circ} \mathrm{C}$ (Fig. $6 \mathrm{c}$ ) shows pseudo-hexagonal thin plates of nepheline growing in a uniaxial arrangement, producing aggregates with an unusual pinecone-like structure. Hexagonal tabular plates are the characteristic morphology of tridymite $\left(\mathrm{SiO}_{2}\right)$. Hence, both the high silica content in the EDS analyses and the tabular morphology of the crystals suggest that nepheline development proceeds through a stuffed derivative structure of silica [51,52]. Accordingly, the structure of nepheline $\left((\mathrm{Na}, \mathrm{K}) \mathrm{AlSiO}_{4}\right)$ can be derived from the structure of high tridymite by substituting $\mathrm{NaAl}$ for Si to form structures with planar wurtzite-type nets [53].

The thermal treatment at $750^{\circ} \mathrm{C}$ leads to an increase in the crystallisation degree, as indicated by the attenuation of the amorphous halo observed in the diffraction pattern (Fig. 7a). The nepheline phase remains the predominant crystalline phase, and its diffraction intensity increases significantly compared to the diffractogram at lower temperature, although low intensity diffraction peaks corresponding to forsterite are also detected. FESEM observations (Fig. 7b) allow both the residual glass and crystalline phases to be distinguished, and the latter phase is composed of crystals with two different morphologies. The differences in the EDS analyses collected from these crystals (Table 2), especially in the magnesium content, make it possible to associate each crystal morphology with a crystalline phase identified by XRD. Thus, the elongated and flattened bladed crystals correspond to nepheline, which grows surrounding or mingling with the residual glassy phase. Frequently, nepheline crystals exhibit a lamellar twinned microstructure, as shown in Fig. 7c. The pinecone aggregates of nepheline crystals observed at $700^{\circ} \mathrm{C}$ are undetectable at higher temperatures. In the case of the forsterite phase (F), crystals develop as thin flakes or plates arranged in a flattened radial habit around a central point, giving rise to rose-shaped clusters of crystals. The forsterite plates always grow in association with nepheline crystals, and it is possible to observe the development of forsterite flakes embedded into nepheline crystals, as shown in Fig. 7d. Fig. 7e shows a FESEM image together with the elemental mapping of $\mathrm{Na}$ (red colour) and $\mathrm{Mg}$ (green colour). The nepheline and forsterite phases are clearly identified by colour dissimilarities caused by different concentrations of these ions in each of the crystalline phases.

The increase of the thermal treatment temperature to $800^{\circ} \mathrm{C}$ leads to negligible changes in both the mineralogy and microstructure of the resulting glass-ceramics (Fig. 8). The XRD pattern depicts a similar distribution of the amorphous and crystalline phases, and the morphology and arrangement of the crystalline phases is comparable to that observed at $750^{\circ} \mathrm{C}$. 
M.I. Martín, F. Andreola, L. Barbieri, F. Bondioli, I. Lancellotti, J.Ma. Rincón, M. Romero1. Crystallisation and microstructure of nepheline-forsterite glass-ceramics. Ceramics International, 39(2013) 2955-2966; doi: 10.1016/j.ceramint.2012.09.07240
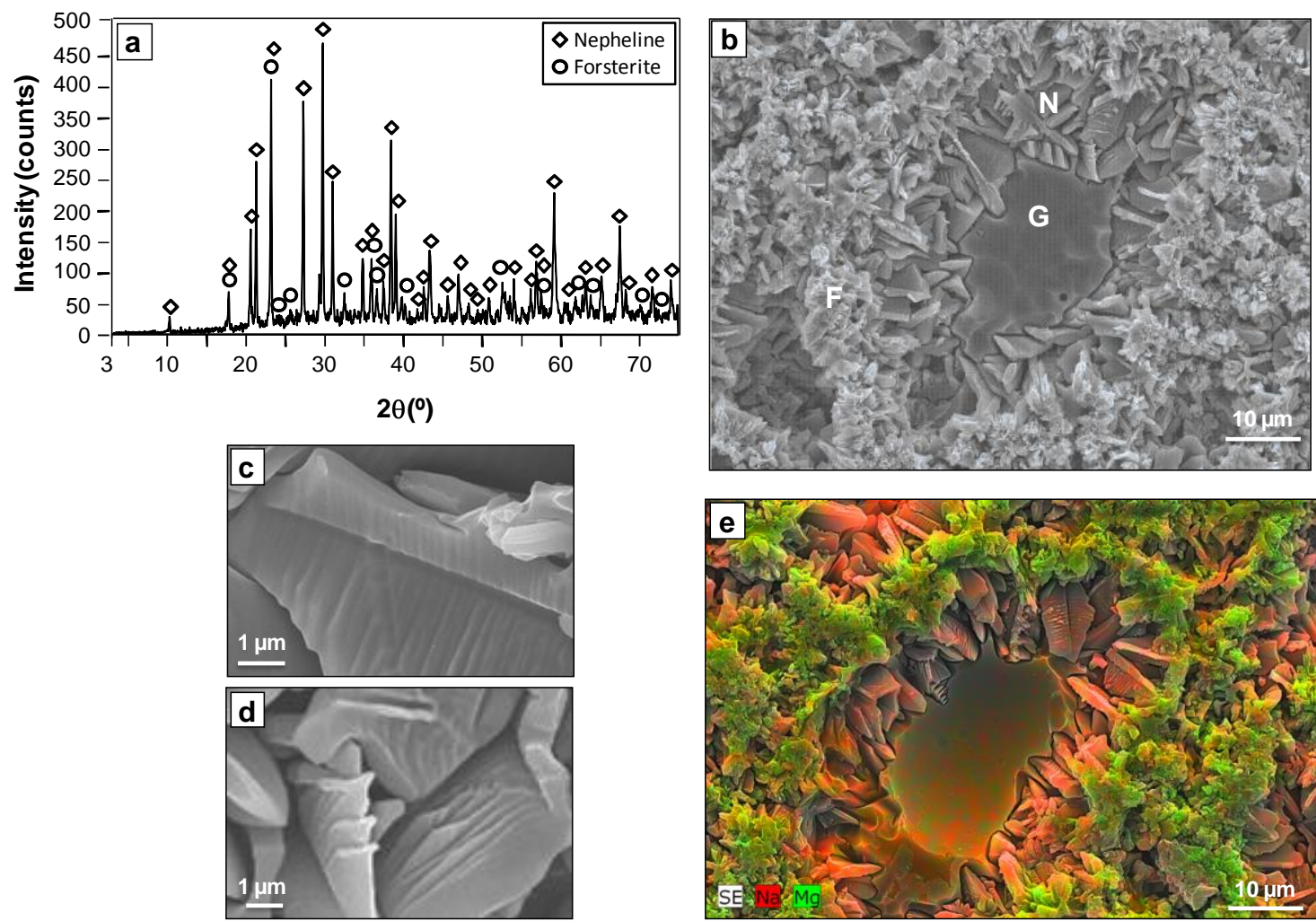

Fig. 7. XRD pattern (a), secondary electron image (b), detail of the microstructure of nepheline and forsterite (c, d) and secondary electron image together with the elemental mapping of $\mathrm{Na}$ (red color) and $\mathrm{Mg}$ (green color) (e) of the sample heat-treated at $750^{\circ} \mathrm{C}$ for 40 minutes $(\mathrm{G}=$ glassy phase, $\mathrm{N}=$ nepheline, $\mathrm{F}=$ forsterite).
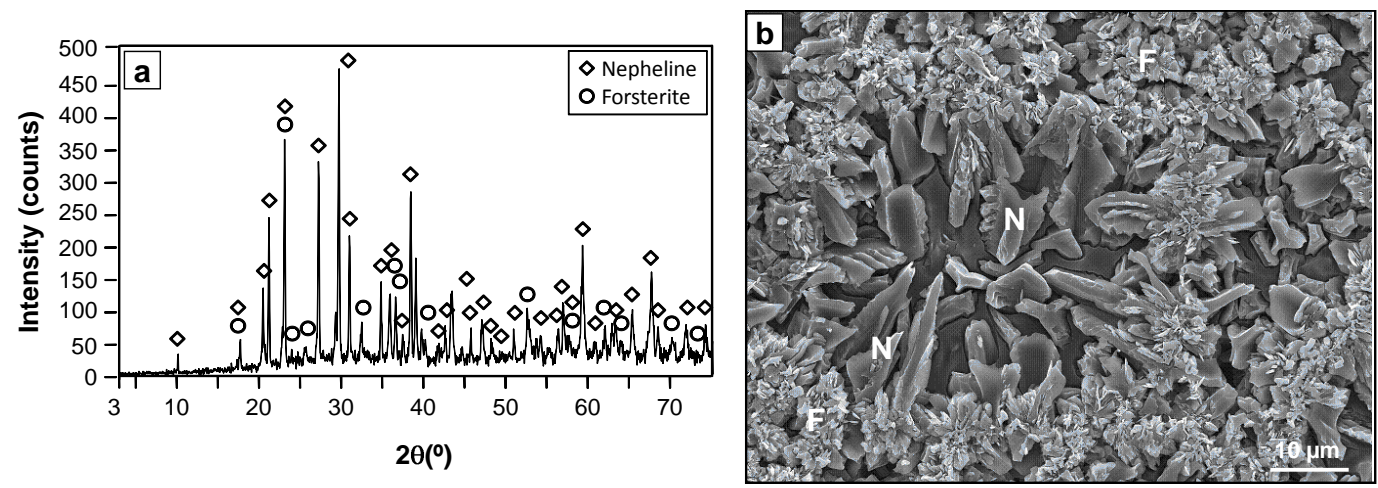

Fig. 8. XRD pattern (a) and secondary electron image (b) of the sample heat-treated at $800^{\circ} \mathrm{C}$ for 40 minutes $(\mathrm{N}=$ nepheline, $\mathrm{F}=$ forsterite $)$. 
M.I. Martín, F. Andreola, L. Barbieri, F. Bondioli, I. Lancellotti, J.Ma. Rincón, M. Romero1. Crystallisation and microstructure of nepheline-forsterite glass-ceramics. Ceramics International, 39(2013) 2955-2966; doi: 10.1016/j.ceramint.2012.09.07240

The most significant microstructural and mineralogical changes are observed after the thermal treatment at $900^{\circ} \mathrm{C}$ (Fig. 9). The intensity of the nepheline peaks in the XRD diffractogram (Fig. 9a) decrease considerably, and the amorphous halo intensifies simultaneously. This result indicates the partial dissolution of the nepheline crystals developed at lower temperatures, thus increasing the amount of the glassy phase, as shown in the FESEM micrograph (Fig. 9b). The treatment at $900^{\circ} \mathrm{C}$ also leads to a new change in the morphology of the nepheline crystals, which appear as hexagonal prisms (the hexagonal morphology is more clearly shown in Fig. $10 \mathrm{~b})$. The proportion of the forsterite phase in the glass-ceramic is nearly invariable, as indicated by the comparable intensity of the forsterite peaks in the diffractograms at $800^{\circ} \mathrm{C}$ and $900^{\circ} \mathrm{C}$. Nevertheless, some microstructural variations with respect to the forsterite crystals developed at $800^{\circ} \mathrm{C}$ are observed. Fig. 10 shows higher magnification observations of the forsterite crystals in the glass-ceramics produced at both $800^{\circ} \mathrm{C}$ and $900^{\circ} \mathrm{C}$. At $800^{\circ} \mathrm{C}$, most of the forsterite crystals are linked to nepheline crystals, producing the rose-shaped aggregates (Fig. 10a) described above. These aggregates develop in minor amounts in the materials obtained at $900^{\circ} \mathrm{C}$ (Fig. 10b) and the partial dissolution of nepheline causes most of the forsterite flakes that appeared at $800^{\circ} \mathrm{C}$ embedded into nepheline crystals to become isolated and to be included in the glassy phase.
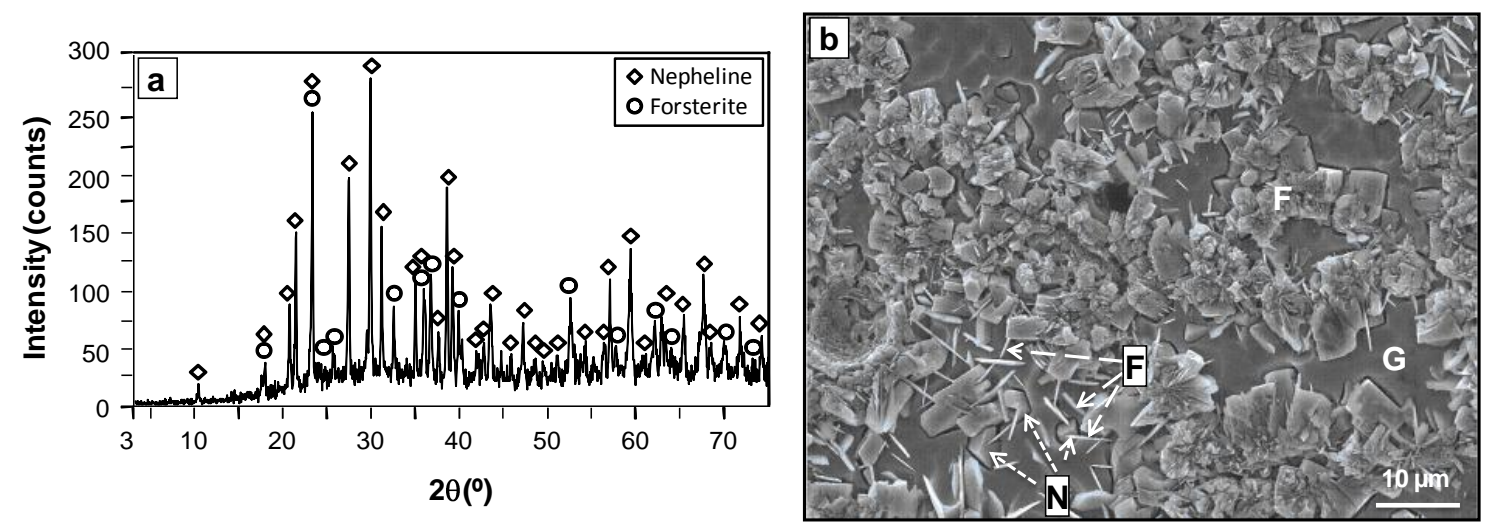

Fig. 9. XRD pattern (a) and secondary electron image (b) of the sample heat-treated at $900^{\circ} \mathrm{C}$ for 40 minutes $(\mathrm{G}=$ glassy phase, $\mathrm{N}=$ nepheline, $\mathrm{F}=$ forsterite).

The dissolution of the nepheline crystals and the subsequent increase in the glassy phase is even more remarkable in the glass-ceramics produced at $1000^{\circ} \mathrm{C}$, as can be observed in both the XRD diffractogram (Fig. 11a) and the FESEM observation (Fig. 11b). The amorphous halo is significantly enhanced by the greater dissolution of the nepheline phase, and the intensity of the diffraction peaks associated to forsterite increases. Forsterite flakes appear randomly oriented and interlocking with each other, leading to a house-of-cards microstructure. The glassy phase, which was observed with a homogeneous morphology at lower temperatures, exhibits a 
M.I. Martín, F. Andreola, L. Barbieri, F. Bondioli, I. Lancellotti, J.Ma. Rincón, M. Romero1. Crystallisation and microstructure of nepheline-forsterite glass-ceramics. Ceramics International, 39(2013) 2955-2966; doi: 10.1016/j.ceramint.2012.09.07240

characteristic texture at $1000^{\circ} \mathrm{C}$. A higher magnification FESEM micrograph (Fig. 11c) allows for observation of the occurrence of numerous small granules, which correspond to the remains of the nepheline crystals that undergo dissolution by the glassy phase.
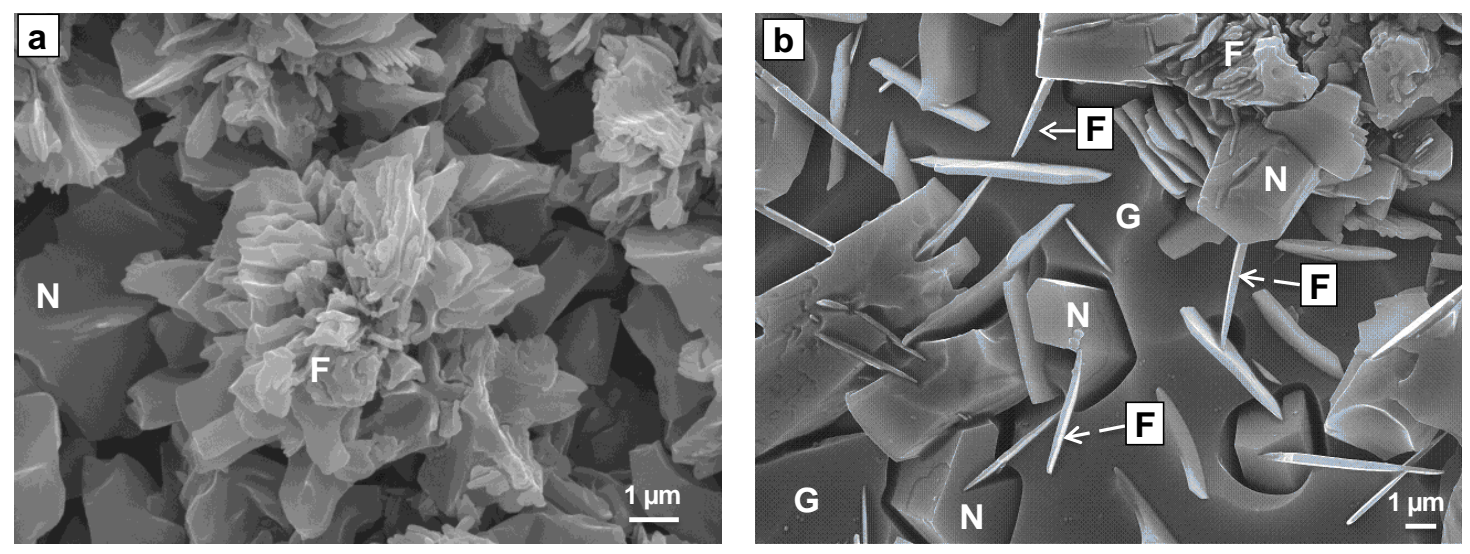

Fig. 10. Secondary electron images of the samples heat-treated at $800^{\circ} \mathrm{C}$ (a) and $900^{\circ} \mathrm{C}$ (b) for 40 minutes $(\mathrm{G}=$ glassy phase, $\mathrm{N}=$ nepheline, $\mathrm{F}=$ forsterite $)$.
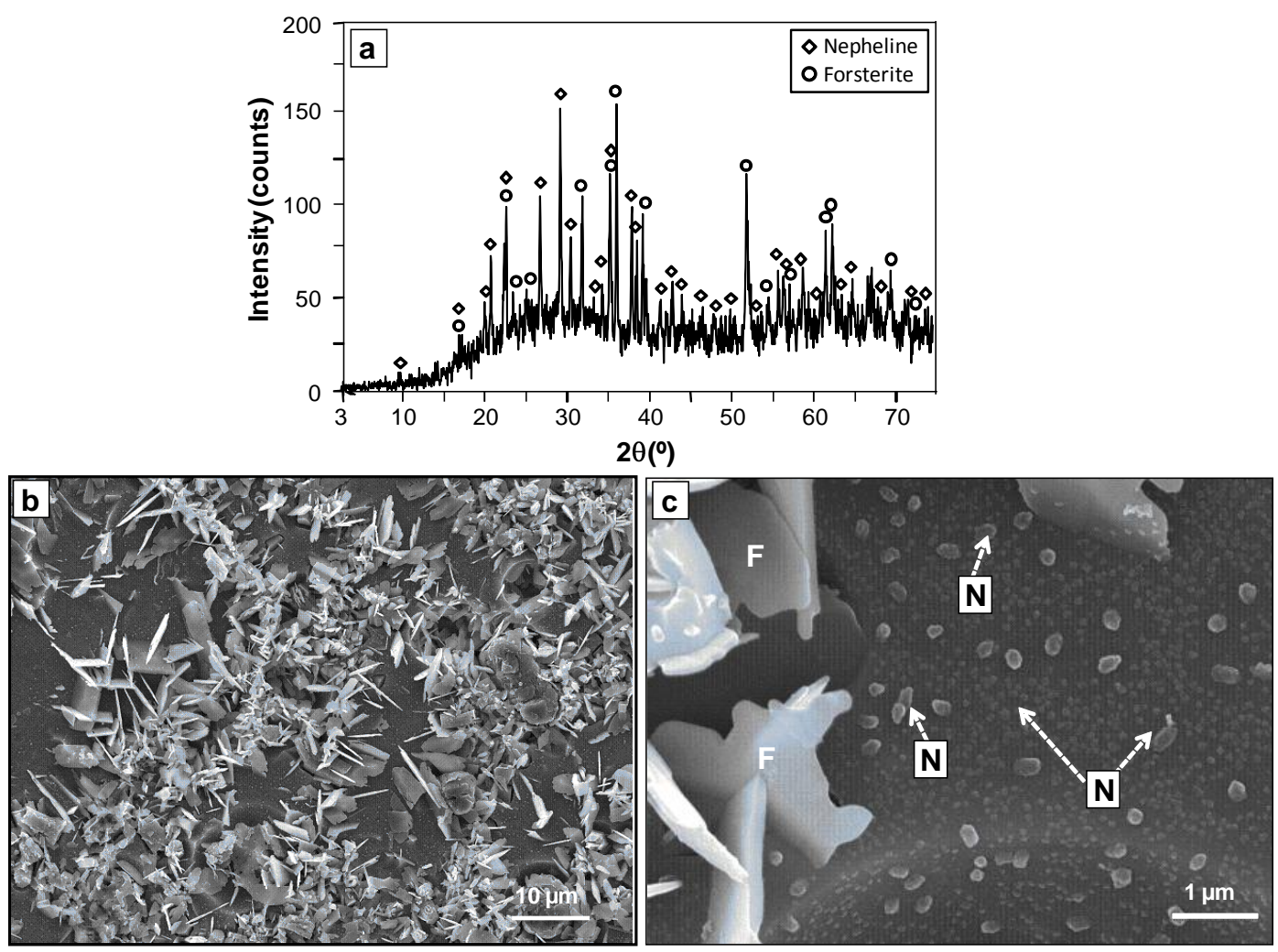

Fig. 11. XRD pattern (a) and secondary electron images (b) x1500, (c) x16000 of the sample heat-treated at $1000^{\circ} \mathrm{C}$ for 40 minutes $(\mathrm{N}=$ nepheline, $\mathrm{F}=$ forsterite $)$. 
M.I. Martín, F. Andreola, L. Barbieri, F. Bondioli, I. Lancellotti, J.Ma. Rincón, M. Romero1. Crystallisation and microstructure of nepheline-forsterite glass-ceramics. Ceramics International, 39(2013) 2955-2966; doi: 10.1016/j.ceramint.2012.09.07240

The chemical composition of the different crystalline phases developed on heating (Table 2) generally exhibit insignificant compositional differences with increasing temperature. As expected, the magnesium ions are mainly retained in the forsterite crystals and the aluminium ions are mainly retained in the glassy phase after crystallisation. The sodium ions assume similar proportions in both the glassy phase and the nepheline crystals. Although the silicon is located in different phases, its content in the glassy phase is slightly higher. The only significant difference found is the evolution of the $\mathrm{SiO}_{2} / \mathrm{MgO}$ ratio in the glass phase and in forsterite crystals developed at different temperatures. Thus, as the forsterite content increases with increasing crystallisation temperature, the percentage of magnesium in the forsterite crystals increases with the consequent decrease in the $\mathrm{SiO}_{2} / \mathrm{MgO}$ ratio, while this ratio increases in the glassy phase.

For a previous knowledge of technological features of these materials, the glass-ceramic obtained after thermal treatment at $900^{\circ} \mathrm{C} / 40 \mathrm{~min}$ has been tested in order to determine its water absorption $(0.41 \%)$, bending strength $\left(39 \mathrm{~N} / \mathrm{mm}^{2}\right)$ and Mohs hardness (8) values. With these properties, the developed glass-ceramic are within BIa group (dry pressed ceramic tiles with water absorption $\mathrm{E}<0.5 \%$ ) of the standard ISO 13006 and are suitable for floor pavement and wall covering in both indoor and outdoor applications. Currently, a study is being conducted to determine the technological properties of the forsterite-nepheline glass-ceramics produced at different thermal treatments to assess their possible fields of application, including their use as ceramic tiles.

\section{Conclusions}

The results obtained in this investigation show the feasibility of the production of a wide variety of forsterite-nepheline glass-ceramics with different microstructure by a sinter-crystallisation process from a $\mathrm{SiO}_{2}-\mathrm{Al}_{2} \mathrm{O}_{3}-\mathrm{MgO}-\mathrm{Na}_{2} \mathrm{O}$ base glass formulated with rice husk ash ( $\mathrm{RHA}$ ) as a silica source.

The DTA curve shows two exothermic effects centred at 745 and $900^{\circ} \mathrm{C}$, which correspond to nepheline $\left(\mathrm{Na}_{2} \mathrm{O} \cdot \mathrm{Al}_{2} \mathrm{O}_{3} \cdot 2 \mathrm{SiO}_{2}\right)$ and forsterite $\left(2 \mathrm{MgO} \cdot \mathrm{SiO}_{2}\right)$ devitrification, respectively. The activation energies associated with these crystallisation processes are $391 \mathrm{~kJ} / \mathrm{mol}$ for nepheline formation and $160 \mathrm{~kJ} / \mathrm{mol}$ for forsterite formation. 
M.I. Martín, F. Andreola, L. Barbieri, F. Bondioli, I. Lancellotti, J.Ma. Rincón, M. Romero1. Crystallisation and microstructure of nepheline-forsterite glass-ceramics. Ceramics International, 39(2013) 2955-2966; doi: 10.1016/j.ceramint.2012.09.07240

Glass begins to crystallise after 40 minutes at $700^{\circ} \mathrm{C}$ and that the glass compacts are fully devitrified after 15 minutes at $750^{\circ} \mathrm{C}$. The fastest rate of crystallisation occurs at $950^{\circ} \mathrm{C}$, at which the onset time for crystallisation is only 2 minutes. The main crystalline phases in the glassceramic materials are nepheline in the temperature interval $700-950^{\circ} \mathrm{C}$ and forsterite at temperatures above $950^{\circ} \mathrm{C}$.

In the early stages of crystal growth $\left(700^{\circ} \mathrm{C}\right)$, the glass-ceramic exhibits a typical coast-andisland microstructure and nepheline appears as pseudo-hexagonal thin plates growing in a uniaxial arrangement, producing aggregates with a pinecone-like structure. At higher temperatures, nepheline develops as elongated and flattened bladed crystals, which frequently exhibit a lamellar twinned microstructure. In the case of the forsterite phase, crystals develop as thin flakes or plates arranged in a flattened radial habit around a central point, giving rise to rose-shaped clusters of crystals. The most significant microstructural and mineralogical changes are observed after the thermal treatment at $900^{\circ} \mathrm{C}$. Nepheline crystallises as hexagonal prisms and forsterite flakes appear randomly oriented and interlocking, leading to a house-of-cards microstructure.

\section{Acknowledgments}

Dr. M.I. Martín expresses her gratitude to the Spanish National Research Council (CSIC) for her contract through the JAE Program (JAEDoc-08-00032), co-financed by the European Social Fund. The authors thank Mrs. P. Díaz for her technical assistance and IRICA from the University of Castilla-La Mancha (Spain) for experimental assistance with XRD.

\section{References}

[1] W. Hölland, G. Beall, Glass-Ceramic Technology, The American Ceramic Society, Ohio, 2002.

[2] E. Willhauk, R. Harikantha, Low thermal expansion glass-ceramics, 2nd ed. Springer Verlag, Heidelberg, 2005.

[3] N. Kanchanarat, S. Bandyopadhyay-Ghosh, I.M. Reaney, I.M. Brook, P.V. Hatton, Microstructure and mechanical properties of fluorcanasite glass-ceramics for biomedical applications, J. Mater. Sci. 43 (2008) 759-765.

[4] R. Casasola, J.Ma. Rincón, M. Romero, Glass-ceramic glazes for ceramic tiles - A review, J. Mater. Sci. 47 (2012) 553-582. 
M.I. Martín, F. Andreola, L. Barbieri, F. Bondioli, I. Lancellotti, J.Ma. Rincón, M. Romero1. Crystallisation and microstructure of nepheline-forsterite glass-ceramics. Ceramics International, 39(2013) 2955-2966; doi: 10.1016/j.ceramint.2012.09.07240

[5] E.I. Suzdal'tsev, D.V. Kharitonov, A.A. Anashkina, Analysis of existing radioparent refractory materials, composites and technology for creating high-speed rocket radomes. Part 4. Ceramic technology for producing glass ceramic radomes. Advantages and disadvantages. Prospects for modernization, Refract. Ind. Ceram. 51 (2011) 349-357.

[6] A.A. Shapiro, N. Kubota, Yu K, M.L. Mecartney, Stress testing of a recrystallizing CaO$\mathrm{B}_{2} \mathrm{O}_{3}-\mathrm{SiO}_{2}$ glass-ceramic with $\mathrm{Ag}$ electrodes for high frequency electronic packaging, $\mathrm{J}$. Electron. Mater. 30 (2011) 386-90.

[7] J.Ma. Rincon, Polym. Principles of nucleation and controlled crystallization of glasses, Plast. Technol. Eng. 31 (1992) 309-357.

[8] S.R. Teixeira, M. Romero, J.Ma. Rincón, Crystallization of $\mathrm{SiO}_{2}-\mathrm{CaO}-\mathrm{Na}_{2} \mathrm{O}$ glass using sugarcane bagasse ash as silica source, J. Amer. Cer. Soc. 93 (2010) 450-455.

[9] W.A. Deer, R.A. Howie, J. Zussman, An introduction to the rock-forming minerals, 2nd ed., Pearson, London, 1992.

[10] L. Lin, M. Yin, C. Shi, W. Zhang, Luminiscence properties of a new red long-lasting phosphor $\mathrm{Mg}_{2} \mathrm{SiO}_{4}: \mathrm{Dy}^{3+}, \mathrm{Mn}^{2+}$, J. Alloys Compd. 455 (2008) 327-330.

[11] S. Ni, L. Chou, J. Chang, Preparation and characterization of forsterite $\left(\mathrm{Mg}_{2} \mathrm{SiO}_{4}\right)$ bioceramics, Ceram. Int. 33 (2007) 83-88.

[12] H.E. Swanson, E. Targe, Natl. Bur. Stand. (U.S.) Circ 359 (1953) 83-86.

[13] F. Tavangarian, R. Emadi, Mechanical activation assisted synthesis of pure nanocrystalline forsterite powder, J. Alloys Compd. 485 (2009) 648-652.

[14] M.H.E. Martin, C.K. Ober, C.R. Hubbard, W.D. Porter, O.B. Cavin, Poly(methacrylate) Precursors to Forsterite, J. Am. Ceram. Soc. 75 (1992) 1831-1838.

[15] S. Ni, L. Chou, J. Chang, Preparation and characterization of forsterite $\left(\mathrm{Mg}_{2} \mathrm{SiO}_{4}\right)$ bioceramics, J. Ceram. Int. 33 (2007) 83-88.

[16] E. Mustafa, N. Khalil, A. Gamal, Sintering and Microstructure of Spinel-Forsterite Bodies, Ceram. Int. 28 (2002) 663-667.

[17] T.S. Sasikala, M-N. Suma, P. Mohanan, C. Pavithran, M.T. Sebastian, Forsterite-based ceramic-glass composites for substrate applications in microwave and millimeter wave communications, J. Alloys Compd. 461 (2008) 555-559.

[18] P. Amista, M. Cesari, A. Montenero, G. Gnappi, L. Lan, Crystallization behaviour in the system $\mathrm{MgO}-\mathrm{Al}_{2} \mathrm{O}_{3}-\mathrm{SiO}_{2}$, J. Non-Cryst. Solids 192\&193 (1995) 529-533.

[19] Y. Hu, H.T. Tsai, Compositional effect on the crystallization of the cordierite-type glasses, J. Mater. Sci. 36 (2001) 123-129.

[20] S.R. Lacerda, J.M. Oliveira, R.N. Correia, M.H.V. Fernandes, TiO-induced phase separation and crystallization in $\mathrm{SiO}_{2}-3 \mathrm{Ca} \cdot \mathrm{P}_{2} \mathrm{O}_{5}-\mathrm{MgO}$ glass, J. Non-Cryst. Solids 221 (1997) $55-60$.

[21] G. Khater, Crystallizing phases from multi-component silicate glasses in the system $\mathrm{K}_{2} \mathrm{O}$ $\mathrm{CaO}-\mathrm{MgO}-\mathrm{Al}_{2} \mathrm{O}_{3}-\mathrm{SiO}_{2}$, Ceram. Int. 27 (2011) 661-668.

[22] Y. Demirci, E. Günay, Crystallization behavior and properties of cordierite glass-ceramics with added boron oxide, J. Ceram. Proc. Res. 12 (2001) 352-356.

[23] W.A. Deer, R.A. Howie, J. Zussman, An introduction to the rock-forming minerals. 2nd ed., Pearson, London, 1992.

[24] J.F. Mac Dowell, Microwave heating of nepheline glass-ceramics, J. Am. Ceram. Soc. 58 (1975) 258-259.

[25] M.C. Wang, N.C. Wu, M.H. Hon, Preparation of nepheline glass-ceramics and their Application as dental porcelain.Mater, Chem. Phys. 37 (1994) 370-375.

[26] E.M.A. Hamzawy, E.M. El-Meliegy, Preparation of nepheline glass-Ceramics for dental applications, Mater. Chem. Phys. 112 (2008) 432-435. 
M.I. Martín, F. Andreola, L. Barbieri, F. Bondioli, I. Lancellotti, J.Ma. Rincón, M. Romero1. Crystallisation and microstructure of nepheline-forsterite glass-ceramics. Ceramics International, 39(2013) 2955-2966; doi: 10.1016/j.ceramint.2012.09.07240

[27] E.M.A. Hamzawy, E.M. El-Meliegy, Crystallization in the $\mathrm{Na}_{2} \mathrm{O}-\mathrm{CaO}-\mathrm{Al}_{2} \mathrm{O}_{3}-\mathrm{SiO}_{2}-(\mathrm{LiF})$ glass compositions, Ceram. Int. 33 (2007) 227-231.

[28] E.M.A. Hamzawy, C. Leonelli, Crystallization, microstructure and expansitivity of apodumene-nepheline glasses, Glass Sci. Technol. 77 (2004) 289-294.

[29] E.I. Suzdal'tsev, D.V. Kharitonov, A.A. Anashkina, Analysis of existing radioparent refractory materials, composites and technology for creating high-speed rocket radomes. Part 4. Ceramic technology for producing glass ceramic radomes. Advantages and disadvantages. Prospects for modernization, Refract. Ind. Ceram. 51 (2011) 349-357.

[30] M. Romero, M. Kovacova, J.Ma. Rincón, Effect of particle size on kinetics crystallization of an iron-rich glass, J. Mater. Sci. 43 (2008) 4135-4142.

[31] M.S. Hernandez-Crespo, M. Romero, J.Ma. Rincon, Nucleation and crystal growth of glasses produced by a generic plasma arc-process, J. Eur. Ceram. Soc. 26 (2006) 1679-85.

[32] M. Romero, M.S. Hernandez-Crespo, J.Ma. Rincon, Leaching behaviour of a glassy slag and derived glass ceramics from arc plasma vitrification of hospital wastes, Adv. Appl. Ceram. 108 (2009) 67-71.

[33] N. Kanchanarat, S. Bandyopadhyay-Ghosh, I.M. Reaney, Microstructure and mechanical properties of fluorcanasite glass-ceramics for biomedical applications, J. Mater. Sci. 43 (2008) 759-765.

[34] F.A. López, M.I Martín, F.J. Alguacil, J.Ma. Rincón, TA. Centeno, Thermolysis of fibreglass polyester composite and reutilisation of the glass fibre residue to obtain a glassceramic material, J. Anal. Appl. Pyrolysis 93 (2012) 104-112.

[35] M.I. Martín, M. Romero, J.Ma. Rincón, F. Andreola, L. Barbieri, F. Bondioli, I. Lancellotti, Materiales vitrocerámicos del sistema $\mathrm{MgO}-\mathrm{Al}_{2} \mathrm{O}_{3}-\mathrm{SiO}_{2}$ a partir de ceniza de cáscara de arroz, Bol. Soc. Esp. Ceram. Vidr. 50 (2011) 201-206.

[36] F. Bondioli, F. Andreola, L. Barbieri, T. Manfredini, A.M. Ferrari, Effect of rice husk ash (RHA) in the synthesis of $(\mathrm{Pr}, \mathrm{Zr}) \mathrm{SiO}_{4}$ ceramic pigment, J. Eur. Ceram. Soc. 27 (2007) 3483-3488.

[37] F. Bondioli, L. Barbieri, A.M. Ferrari, T. Manfredini, Characterization of rice husk ash and its recycling as quartz substitute for the production of ceramic glazes, J. Amer. Ceram. Soc. 93 (2010) 121-126.

[38] T. Luangvaranunt, C. Dhadsanadhep, J. Umeda, E. Nisaratanaporn, K. Kondoh, Aluminum-4 mass\% copper/alumina composites produced from aluminum copper and rice husk ash silica powders by powder forging, Mater. Trans. 51(2010) 756-761.

[39] G.C. Cordeiro, R.D. Toledo, E.D.R. Fairbairn, Use of ultrafine rice husk ash with highcarbon content as pozzolan in high performance concrete, Mater. Struct. 42 (2009) 983992.

[40] B.K. Ngun, H. Mohamad, E. Sakai, Z.A. Ahmad, Effect of rice husk ash and silica fume in ternary system on the properties of blended cement paste and concrete, J. Ceram. Process Res. 11 (2010) 311-315.

[41] C.S. Prasad, K.N. Maiti, R. Venugopal, Effect of Substitution of Quartz by Rice Husk ash and silica fume on the properties of whiteware Compositions, Ceram. Int. 29 (2003) 907-914.

[42] F. Andreola, L. Barbieri, F. Bondioli, Agricultural waste in the synthesis of coral ceramic pigment, Dyes Pigm. 94 (2012) 207-211.

[43] D. Wattanasiriwech, N. Polpuak, P. Danthaisong, S. Wattanasiriwech, Use of Rice Husk ash for quartz substitution in stoneware glazes, J. Sci. Ind. Res. 67 (2008) 455-460.

[44] F. Andreola, L. Barbieri, F. Bondioli, A.M. Ferrari, T. Manfredini, Valorization of rice husk ash as secondary raw material in the ceramic industry, Proc. 10th Int. Conference of European Ceramic Society (ECERS), Baden-Baden (Germany) 2007, pp. 1794-1798. 
M.I. Martín, F. Andreola, L. Barbieri, F. Bondioli, I. Lancellotti, J.Ma. Rincón, M. Romero1. Crystallisation and microstructure of nepheline-forsterite glass-ceramics. Ceramics International, 39(2013) 2955-2966; doi: 10.1016/j.ceramint.2012.09.07240

[45] J.P. Nayak, S. Kumar, J. Bera, Sol-gel synthesis of bioglass-ceramics using rice husk ash as a source for silica and its characterization, J. Non-Cryst. Solids 356 (2010) 1447-1451.

[46] M.K. Naskar, M. Chatteljee, A novel process for the synthesis of lithium aluminum silicate powders from rice husk ash and other water-based precursor materials, Mater. Lett. 59 (2005) 998-1003.

[47] M.K. Naska, M. Chatterjee, A novel process for the synthesis of cordierite $\left(\mathrm{Mg}_{2} \mathrm{Al}_{4} \mathrm{Si}_{5} \mathrm{O}_{18}\right)$ powders from rice husk ash and other sources of silica and their comparative study, J. Eur. Ceram. Soc. 24 (2004) 3499-3508.

[48] H. Kissinger, Reaction kinetics in differential thermal Analysis, Anal. Chem. 29 (1957) 1702-1706.

[49] http://www.webmineral.com/data/Nepheline.shtml

[50] http://www.mindat.org/min-2880.html

[51] M.J. Buerger, Derivative crystal structures, J. Chem. Phys. 15 (1947) 1-16.

[52] R.N. Abbott, $\mathrm{KAlSiO}_{4}$ Stuffed derivatives of tridymite: phase relationships, Amer. Mineral. 69 (1984) 449-457.

[53] R.B. Heimann, Classic and advanced ceramics: from fundamentals to applications: John Wiley \& Sons, Weinheim, 2010. 